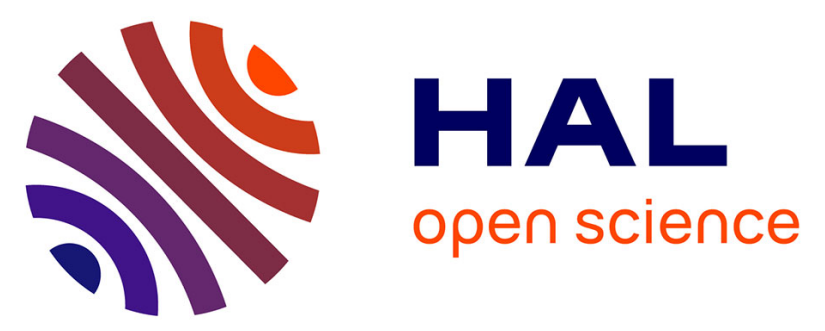

\title{
Fluid-Induced Swarms and Coseismic Stress Transfer: A Dual Process Highlighted in the Aftershock Sequence of the 7 April 2014 Earthquake (Ml 4.8, Ubaye, France)
}

Louis de Barros, Marion Baques, Maxime Godano, Agnès Helmstetter, Anne

Deschamps, Christophe Larroque, Françoise Courboulex

\section{To cite this version:}

Louis de Barros, Marion Baques, Maxime Godano, Agnès Helmstetter, Anne Deschamps, et al.. FluidInduced Swarms and Coseismic Stress Transfer: A Dual Process Highlighted in the Aftershock Sequence of the 7 April 2014 Earthquake (Ml 4.8, Ubaye, France). Journal of Geophysical Research: Solid Earth, 2019, 124 (4), pp.3918-3932. 10.1029/2018JB017226 . hal-02200605

\section{HAL Id: hal-02200605 \\ https://hal.science/hal-02200605}

Submitted on 25 Nov 2021

HAL is a multi-disciplinary open access archive for the deposit and dissemination of scientific research documents, whether they are published or not. The documents may come from teaching and research institutions in France or abroad, or from public or private research centers.
L'archive ouverte pluridisciplinaire HAL, est destinée au dépôt et à la diffusion de documents scientifiques de niveau recherche, publiés ou non, émanant des établissements d'enseignement et de recherche français ou étrangers, des laboratoires publics ou privés.

$$
\text { Copyright }
$$




\author{
RESEARCH ARTICLE \\ 10.1029/2018JB017226 \\ Key Points: \\ - Improved detection, classification, \\ and location of the aftershock \\ sequence following the $\mathrm{Ml} 4.8$ \\ earthquake in the French Alps \\ - Event sources align consistently \\ along the mainshock fault, but on \\ structures of its damaged zone or to \\ small faults further away \\ - Spatial separation of two different \\ processes: coseismic stress transfer \\ close to the mainshock and \\ fluid-pressure diffusion further \\ away
}

Supporting Information:

- Supporting Information S1

- Movie S1

Correspondence to:

L. De Barros,

debarros@geoazur.unice.fr

Citation:

De Barros, L., Baques, M., Godano, M. Helmstetter, A., Deschamps, A.,

Larroque, C., \& Courboulex, F. (2019). Fluid-induced swarms and coseismic stress transfer: A dual process highlighted in the aftershock sequence of the 7 April 2014 earthquake (Ml 4.8, Ubaye, France). Journal of Geophysical Research: Solid Earth, 124, 3918-3932. https://doi.org/10.1029/2018JB017226

Received 20 DEC 2018

Accepted 17 MAR 2019

Accepted article online 21 MAR 2019

Published online 11 APR 2019

(c)2019. American Geophysical Union. All Rights Reserved.
Fluid-Induced Swarms and Coseismic Stress Transfer: A Dual Process Highlighted in the Aftershock Sequence of the 7 April 2014 Earthquake (Ml 4.8, Ubaye, France)

\author{
Louis De Barros ${ }^{1}\left(\mathbb{D}\right.$, Marion Baques ${ }^{1}$, Maxime Godano ${ }^{1}$, Agnès Helmstetter ${ }^{2}$ (D), \\ Anne Deschamps ${ }^{1}$ (D), Christophe Larroque ${ }^{1}$, and Francoise Courboulex ${ }^{1}$ \\ ${ }^{1}$ Université Côte d'Azur, CNRS, OCA, IRD, Géoazur, Sophia Antipolis, Valbonne, France, ${ }^{2}$ Université Grenoble Alpes, \\ Université Savoie Mont Blanc, CNRS, IRD, IFSTTAR, ISTerre, Grenoble, France
}

Abstract The upper part of the Ubaye Valley (French Alps) is characterized by alternating mainshock-aftershock sequences and swarms. Particularly, during the 2012-2015 crisis, four mainshocks with $\mathrm{Ml}>3.5$ occurred. We here focus on the aftershocks of the largest one ( $\mathrm{Ml}=4.8,7$ April 2014), in order to better understand the involved processes behind this peculiar seismic behavior. We use template matching detection, waveform classification, and double-difference relocations to analyze this seismicity, on average and at the scale of the clusters that compose it. Most event sources are aligned along a plane consistent with the mainshock fault $\left(\mathrm{N} 165,65^{\circ} \mathrm{W}\right)$, but occurred on conjugate structures. A few clusters of seismicity are also observed far from the mainshock source. Our analysis shows that distinct, spatially separated processes are at play. While coseismic stress transfer explains the seismicity close to the mainshock source, fluid-pressure diffusion and distant stress triggering are required to generate events farther away. The overall distributions in time and magnitude followed a slow Omori's decay and a Gutenberg-Richter relationship, respectively. However, these classical responses arise from the superposition of very different behaviors, associated with different processes at depth.

Plain Language Summary Earthquakes have regularly shaken the upper part of the Ubaye valley, near the town of Barcelonnette in the Southwestern French Alps, for nearly 20 years. The earthquake behavior is peculiar, as swarms of numerous low magnitude events alternate with larger earthquakes, such as the Ml 4.8 one occurring on 7 April 2014. To understand this dual behavior, we performed an in-depth analysis of the aftershock of this event. The seismicity mainly aligns on a plane consistent with the mainshock fault $\left(\mathrm{N} 165,65^{\circ} \mathrm{W}\right)$. However, most of the events occurred on branching structures, belonging to the damaged zone of this fault, or on some other small faults far away. While the average behavior of this aftershock sequence is close to a standard one, we show that two different processes occurred at depth. Events occurring close to the mainshock are triggered by coseismic stress transfer, while fluid-pressure diffusion are likely required to explain the seismicity further away. Such dual process should be considered for seismic hazard assessment.

\section{Introduction}

Earthquakes commonly occur either as mainshock-aftershock sequences or as seismic swarms. Mainshockaftershock sequences are characterized by the occurrence of a large magnitude event, followed by a decaying series of smaller events. The latter are primarily related to the coseismic static stress transfer (Stein, 1999), but also to dynamic stress changes (Felzer \& Brodsky, 2006), coseismic fluid pressurization (Miller et al., 2004), or aseismic afterslip (Perfettini \& Avouac, 2004). A swarm activity is characterized by a localized cluster of seismicity, without a clear onset, as the largest event occurs in the middle of the sequence. In space, the size of the swarm is much larger than the rupture length of the largest event (Vidale \& Shearer, 2006), so that Coulomb static stress changes cannot explain the triggering of the sequence. An additional forcing is thus required to explain the triggering at large distances and the long duration. It can be associated to fluids from meteoric origin (e.g., West Bohemian swarm, Hainzl et al., 2012), pervasive in the faulted crusts (e.g., Corinth Gulf, Duverger et al., 2015), or linked to anthropic activities (e.g., waste water disposal in Oklahoma, Keranen et al., 2014). Seismic swarms are also observed driven by slow, aseismic slips, on 
creeping faults, such as on parts of the San Andreas fault (Waldhauser et al., 2004), in subduction areas (Vallée et al., 2013), and in central Italy (Collettini \& Barchi, 2002).

Therefore, aftershock sequences and swarms may share common driving processes, related to fluids or to aseismic slip. These processes may be intertwined, as fluid flow, aseismic slip, and stress transfer may be simultaneously at play. For example, aseismic creep might induce fault dilatancies, which perturb the fluid distribution at depth, sustaining the aseismic motion and leading to seismicity by stress transfer (De Barros et al., 2018; Guglielmi et al., 2015). Therefore, the driving mechanisms of both swarms and aftershocks are still questionable, especially if a full continuum of behaviors exists between these two end-members. This question is particularly relevant for areas that are alternatively struck by mainshocks and seismic swarms, as the latter may evolve to the first one. For example, the seismicity in the Gulf of Corinth is mainly characterized by swarms (Duverger et al., 2015), with large and damaging earthquakes occasionally (e.g., M 6 Aigion earthquake, Bernard et al., 1997). The l'Aquila earthquake ( $\mathrm{Mw}=6.2,2009$, central Italy) occurred after a 2-month-long swarm-like crisis, interpreted as driven by a slow-slip event (Borghi et al., 2016). Therefore, in order to understand the overall behavior of a seismic area, it is of crucial importance to understand what the driving processes are and how they interact. Such processes, which are still under debate, may be inferred by the analysis of either seismic swarms or aftershock sequences, as both share similarities.

We focus on the peculiar aftershock sequences following the 7 April 2014 earthquake $(\mathrm{Ml}=4.8)$ in the Ubaye Valley. This area is the most active one in the French Alps. It has been frequently struck both by mainshocks with magnitude close to 5 (Thouvenot et al., 2016) and by several swarms, attributed to fluid migration (Jenatton et al., 2007; Leclère et al., 2013). The alternating swarms and mainshock/aftershock sequences make this area of scientific interest. Particularly, it was seismically active between 2012 and 2017, with more than 13,000 events of magnitude greater than 0.5 , including four mainshocks with $\mathrm{Ml}>3.5$. As (1) the seismicity rate never came back to the pre-2012 rate, and (2) the largest event occurred in the middle of the sequence, the overall distribution of this crisis suggests a swarm behavior. After the 2014 mainshock, a dense network of postseismic temporary stations was installed at less than $10 \mathrm{~km}$ around the epicenter (see Figure 1). This aftershock sequence is of particular interest as the decay in the number of event is slower than expected by an Omori's law. By studying in details this sequence, we aim at identifying the driving process of the seismicity in this area, in order to understand the reason of such a peculiar behavior. Using a template matching detection and accurate relocation, we will zoom inside the seismic cluster and focus on the different families that compose it. Doing so, we will isolate the aftershocks, driven by coseismic stress transfer, from the swarm-like events, and we will separately analyze their spatiotemporal behavior.

\section{Seismotectonic Context}

The Ubaye valley is located in the southwestern Alps, close to the suture between Europe and the colliding Adriatic microplate (e.g., Dewey et al., 1989). The Paleozoic crystalline rocks of the Argentera massif are there overlapped by a 2-km-thick sedimentary cover made of the autochtonous Mesozoic and Cenozoic sediments of the Dauphinois domain and by the allochtonous unit of the Embrunais-Ubaye nappes which was thrusted onto the autochtonous during the Oligo-Miocene times (Corsini et al., 2004; Fry, 1989). Therefore, the crust displays numerous faults inherited from the Hercynian and Alpine orogenies and from the ongoing deformation in the Pliocene (Bigot-Cormier et al., 2000; Bogdanoff et al., 2000; Sue \& Tricart, 2003). In Argentera-Ubaye, the major faults belong to a NW-SE system of subvertical right-lateral faults mainly activated during the Oligocene-Miocene times and whose current activity is being discussed (Larroque et al., 2001; Sanchez et al., 2010). From 2002 to 2016, the seismicity is mainly aligned N130 ${ }^{\circ} \mathrm{E}$ and occurs at 3-8 km depth in the crystalline basement (Daniel et al., 2011; Jenatton et al., 2007; Thouvenot et al., 2016). Unfortunately, no coseismic surface rupture has been identified in the field to confirm this assumption.

At the scale of the western Alps, continuous GPS measurements since 16 years point out a complex deformation pattern with uplift of the axial part of the belt, decreasing from $2 \mathrm{~mm} /$ year in the north to $0.3 \mathrm{~mm} /$ year in the south. This uplift is combined with low East-West extensional deformation (in the range of 10 nanostrain per year) in the center of the belt, including the Ubaye area, while no active shortening is detected between each side of the Alps (Nocquet et al., 2016; Walpersdorf et al., 2018). Therefore, the present-day dynamic of the western Alps is under discussion and results certainly of a combination of processes such 


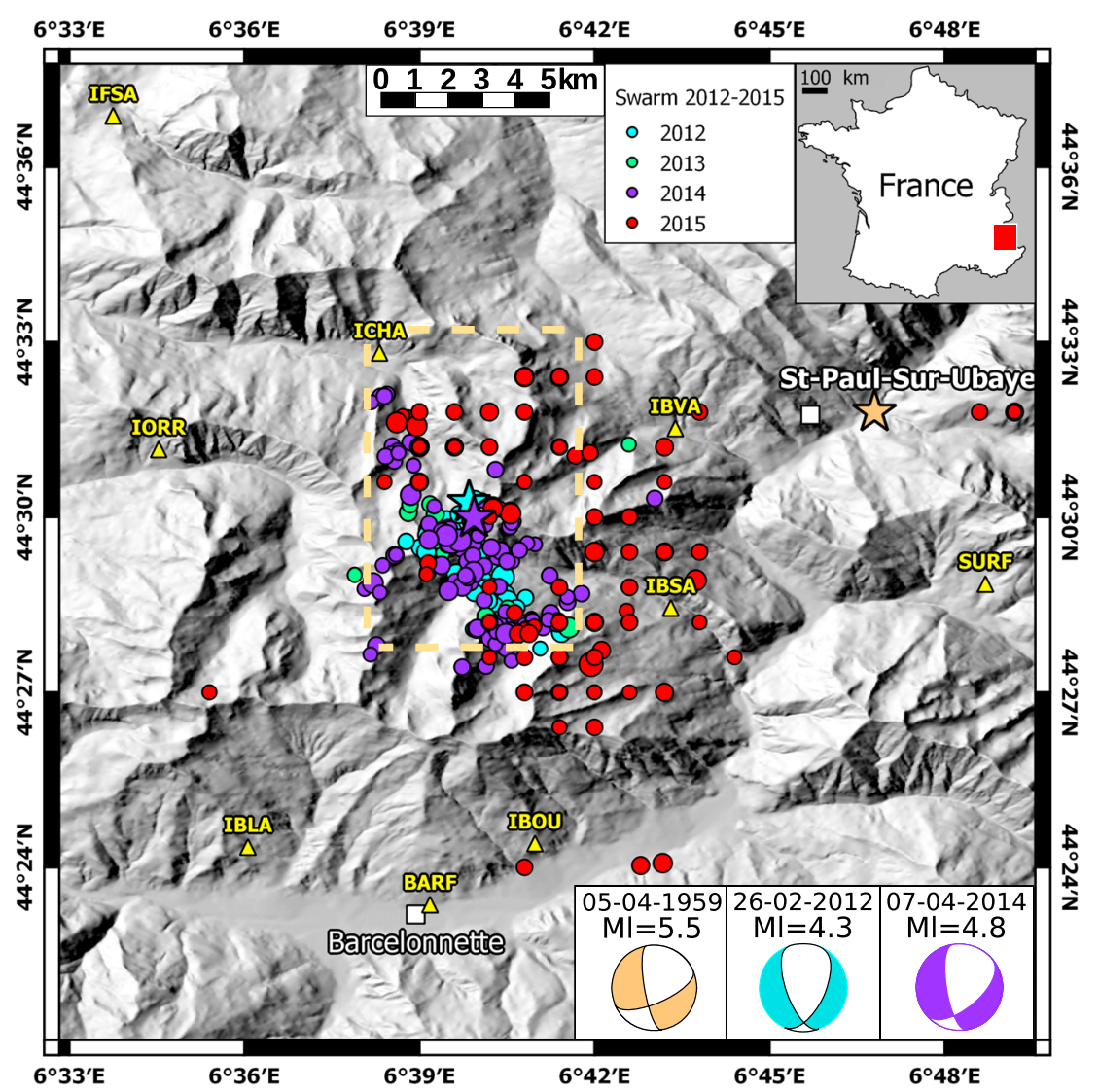

Figure 1. Map of the upper Ubaye valley in the French Alps and general overview of the seismicity. Top right inset shows the location in France. Topography is shown as gray shaded area, with main towns represented as white squares. The largest events $(\mathrm{Ml} \geq 1.5)$ of the 2012-2016 swarms are colored by year, with size related to magnitudes (Sismalp catalog, Thouvenot et al., 2016). The main earthquakes in the area (1959, 2012, and 2014) are shown as stars, with their mechanisms given in the bottom right insets. Yellow triangles show the nine seismic stations used in this study. The dashed orange rectangles indicate the studied area.

as buoyancy effects (Larroque et al., 2009), deep asthenospheric processes (Zhao et al., 2015), erosional unloading (Vernant et al., 2013), and/or postglacial rebound (Nocquet et al., 2016). Whatever, in Ubaye, the extensional deformation highlighted by the geodetic measurements is consistent with the observed earthquake mechanisms.

Nowadays, the Ubaye valley is the most active seismic zone in the French Alps. This area is indeed regularly struck either by seismic swarms of small magnitude events or by classical mainshock/aftershock sequences. Historically, one of the largest earthquakes in the French Alps (Ml 5.5) occurred on 5 April 1959 (Nicolas et al., 1990). Seismic swarms occurred then in 1978, 1989, and 2003-2004 (Fréchet \& Pavoni, 1979). The latter, with more than 16,000 detected events, clustered on a $9 \mathrm{~km}$ long normal/strike-slip fault (Jenatton et al., 2007). Despite this large number of events, no large earthquake occurred currently, as the magnitudes stayed below Ml 2.7. The unfavorable orientation of the faults toward the stress state (Leclère et al., 2012) and the spatiotemporal migration (Daniel et al., 2011) suggest a fluid-induced seismicity. More recently, an intense seismic activity started with a Ml 4.3 earthquake on the 26 February 2012 (22h37 UTC). This event, located a few kilometers NW of the 2003-2004 cluster, occurred beneath the Parpaillon massif, belonging to the Ubaye-Embrunais nappes which peaks at 3,046 $\mathrm{m}$. It was felt by the population, particularly toward the south because of a strong source directivity effect (Courboulex et al., 2013) and caused some structural damages in the epicentral zone. On 7 April 2014 (19h26 UTC), another earthquake occurred at a similar location $(0.3 \mathrm{~km}$ southward and $1 \mathrm{~km}$ downward), with a local magnitude $\mathrm{Ml}$ between 4.8 (Thouvenot et al., 2016) and 5.2 (Sira et al., 2014) and a moment magnitude $\mathrm{Mw}=4.8$. This event was the strongest since 1959 in this area, but also in the French Alps in the last 20 years. Once again, this event 
was a source of concern for the surrounding population, and few damages were noticed on close buildings (maximal EMS98 intensity of VI, Sira et al., 2014). It occurred at about $9 \mathrm{~km}$ depth below sea level, on a $\sim \mathrm{N} 160,55^{\circ} \mathrm{SW}$ fault (Thouvenot et al., 2016). Its focal mechanism, similarly as the 2012 event, show a dominant normal motion, with a right-lateral strike-slip component. Two other mainshocks occurred in 2015 in the same area, with magnitudes of Ml 3.4 (11 April 2015) and 4.2 (6 November 2015). After all those mainshocks, the seismicity decreased (see Figure 2), at rate that can be slower than expected by an Omori's law. Interestingly, the decrease is much slower after the 26 February 2012 event than after the 6 November 2015 event, despite similar magnitudes. It suggests that the aftershock sequences, at least for the 2012 and 2015 events, are not solely driven by coseismic stress transfer. In total, in the 2012-2015 years, more than 13,000 events, with a cut-off magnitude of $\sim 0.5$, were detected and analyzed by Thouvenot et al. (2016). After the 2012 event, but not the 2014 one, a general spatiotemporal migration of the aftershocks toward the South-East is interpreted as due to fluid-pressure diffusion (Thouvenot et al., 2016). The behavior of the 2012 crisis is therefore peculiar: While a mainshock started the crisis, the aftershock sequences share common features with seismic swarms, in the large number of events or in migration patterns (Thouvenot et al., 2016). Furthermore, numerous focal mechanisms are now well constrained and reveal a complex normal-transtensional tectonic regime which strike as the high relief of the western Alps (Delacou et al., 2004; Larroque et al., 2009). As the current ruptures were blind, the active fault extensions and geometry are partly unknown in this area. Therefore, the complex seismological behavior and tectonic context make that the possibility of a large, damaging earthquakes is still an open question.

\section{Data and Methods}

The aftershock sequence of the 7 April 2014 (19h26 UTC) earthquake was initially analyzed by Thouvenot et al. (2016) using the Sismalp network. This network was mainly composed of triggered stations equipped with $1 \mathrm{~Hz}$ seismometers. Apart from four stations, most stations are located a few tens of kilometers away from the swarm area, and up to $150 \mathrm{~km}$. In order to improve (1) the detection capability and (2) the accuracy of the analysis, seven short-period stations, with continuous recordings, were installed after the 2014 mainshock. These seven stations, plus two permanent stations (SURF belonging to the French RESIF network, RESIF, 1995, and BARF belonging to the French Sismo à L'Ecole network) were located at distances smaller than $10 \mathrm{~km}$ from the epicenter area (Figure 1). This network was fully running for 2 months, since 10 April until 15 June 2014.

Events from the 2012-2016 Sismalp catalog (Thouvenot et al., 2016) were used as templates to improve the detection level. We used data from station SURF, the permanent station located closer from the swarm area. Earthquakes were first correlated with each other to group events into families with similar waveforms. An earthquake was associated with a family if the correlation with at least one event from this family was larger than 0.8 . Then we stacked all waveforms inside each family to obtain the template waveforms. We used these templates to look for similar signals in the continuous records of station SURF using a template-matching filter with a minimum correlation of 0.5 (Gibbons \& Ringdal, 2006). Between the 10 April and the 15 June 2014, the Sismalp catalog contains 846 events. We have extended this catalog up to 10,895 events, which have been classified into families with similar waveforms. Within each family, we therefore expect to find events that share similar locations and mechanisms, that is, that originate from the same structure, or to subparallel ones. We then focus on the largest 31 families, containing between 52 and 1,757 events, for a total of 9,027 events.

Fifty events, which are either the largest events of each family or events with magnitude larger than 2 in the Sismalp catalog, were then manually picked on 12 stations and relocated using the double-difference HYPODD software (Waldhauser \& Ellsworth, 2000). These master-events are then used as first guesses for the location of the family centroid. Similarly to Thouvenot et al. (2016), the location is performed using an eight-layer crustal model proposed by Sellami et al. (1995) for the western-part of the Alps.

Inside each family, the travel time differences between pairs of events are then computed using crosscorrelation on short windows around $P$ and $S$ wave arrivals. A pair of events is composed of one event and one among the $\sim 15 \%$ of the events that share the mean highest correlation coefficients with the other. Within each family, as the detection makes the events roughly aligned, $P$ and $S$ waves are manually picked for a single event on all stations, in order to define the position of the windows used for correlation. The 

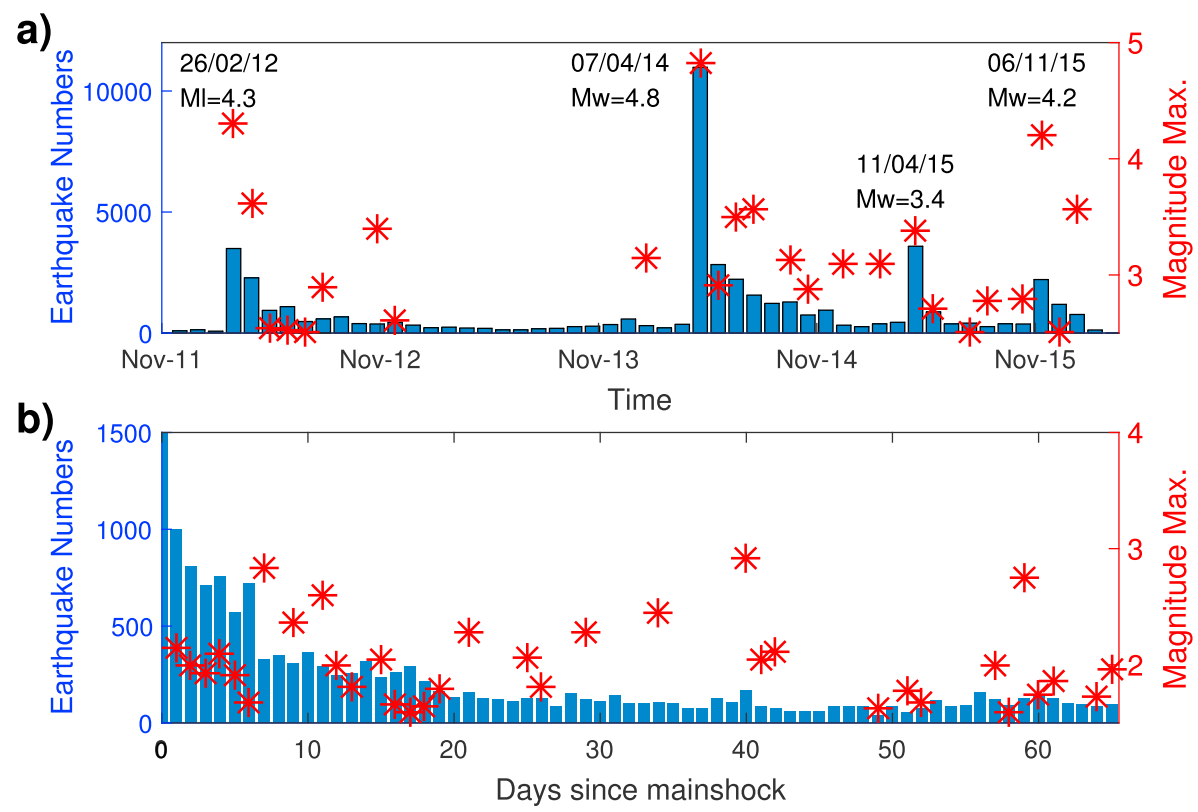

Figure 2. Time distribution of earthquakes and their magnitudes. (a) Monthly rates and maximum magnitude $(\mathrm{Ml}>2.5)$ from November 2011 to March 2016 and (b) daily rates and maximum magnitudes (Ml > 1.5) after the Ml 4.8 mainshock occurring on 7 April 2014.

correlation between events is then made on $2 \mathrm{~s}$ long windows ( $0.4 \mathrm{~s}$ before and $1.6 \mathrm{~s}$ after the picked times, with a 3-15 Hz filtering). Only the travel-time differences with a cross-correlation coefficient higher than $70 \%$ are kept, leading to a total of 161,090 and 688,895 travel-times for $P$ and $S$ waves, respectively. Note that the number of P-travel times is smaller because of its low amplitude on most of the stations. Events inside every family are then relocated separately with the HYPODD software. Finally, the locations of all events are corrected to replace the master-events at their location determined in the first inversion step. In total, 5,947 events were relocated. It represents only $55 \%$ of the detected events, but $700 \%$ of the initial Sismalp catalog.

We then compute location errors. The locations of the family cluster, obtained through the first relative location step, have an uncertainty lower than $30 \mathrm{~m}$ horizontally and $70 \mathrm{~m}$ vertically. Inside a family, the relative errors (second relocation) are found to be less than $10 \mathrm{~m}$ in all directions (see supporting information Figure S1). Despite a very similar cluster shape, the seismicity is observed to be more sharply clustered, with clearer location structures, in our location compared to the ones from Thouvenot et al. (2016). Our locations are, on average, shifted by $\sim 600 \mathrm{~m}$ toward the South-East, and $300 \mathrm{~m}$ shallower. As the same velocity model is used, this discrepancy may come from the station distribution, as our network has stations with well-distributed azimuths and at short distance around the epicenter area. The 7 April 2014 mainshock was not recorded by the temporary stations. We therefore correct the location found by Thouvenot et al. (2016) by these average shifts, which may lead to location uncertainties that might reach several hundred of meters.

We then analyze the geometry of every family cluster by means of two different methods. The 3-point method from Fehler et al. (1987) allows the statistical determination of the most likely poles of the planar structures. This method assumes planar structures, and therefore fails in case of elongated structure. It is however robust when several parallel planes are present. The second method (Michelini \& Bolt, 1986) is based on the eigenvalue decomposition of the covariance matrix, which allows inferring the axis orientation and length of the best fitting ellipsoid, which characterizes the geometry of the structures. Both method results are carefully checked against each other and by visual inspection.

For the events with a magnitude already computed by Sismalp (Thouvenot et al., 2016), we invert the $S$ wave amplitudes and the hypocentral distance to the stations to build a local magnitude law. The errors on this reconstruction are lower than 0.2 , which is then assumed to be the uncertainty on the computed 
a)

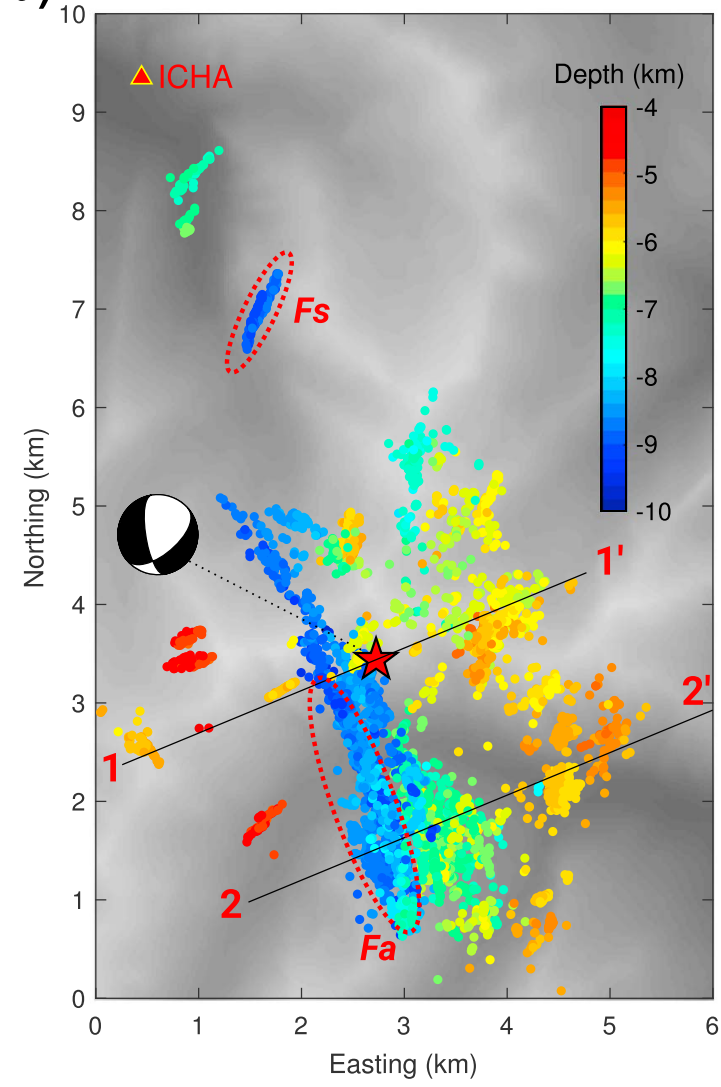

b)

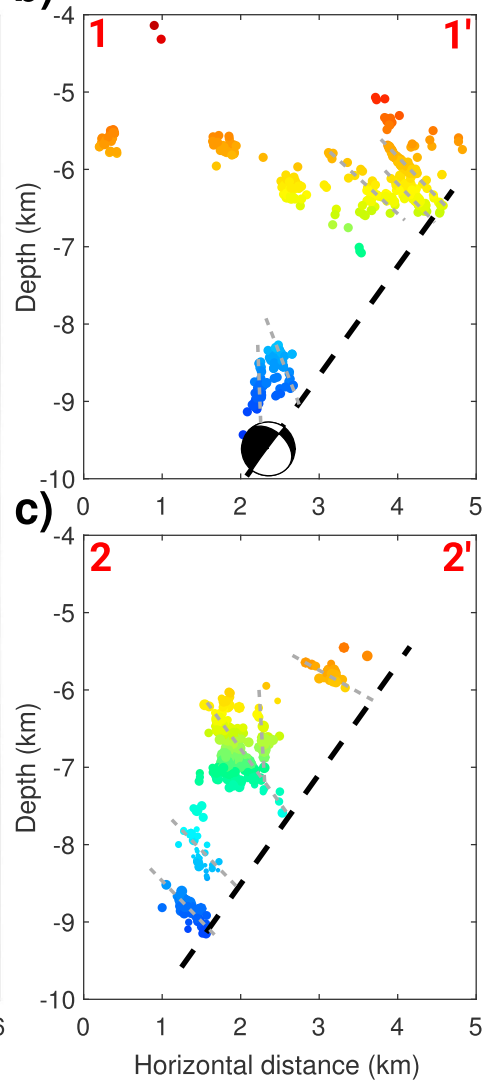

Figure 3. Event locations, colored by depth below sea level. (a) Map view of the seismicity. The star shows the mainshock location. The latitude and longitude reference are $N=44^{\circ} 27^{\prime} 46^{\prime \prime}$ and $\mathrm{E}=6^{\circ} 38^{\prime} 12^{\prime \prime}$, respectively. Events at horizontal distances smaller than $200 \mathrm{~m}$ from the vertical planes $1-1^{\prime}$ and $2-2^{\prime}$ are projected onto those planes, to build the crosssections given in (b) and (c), respectively. On each panel, the size of the location dots refers to the event magnitude. The mainshock mechanism is given on panels (a) and (b), with its fault plane extrapolated in (b) and (c). On panel (a), red ellipses identify the families $\mathrm{Fa}$ and Fs used as examples in this study. On panels (b) and (c), light gray dashed lines schematically show the event alignments. The evolution of the locations with time is shown in the Movie S1.

magnitudes. This law then allows for the extrapolation of the magnitude computation to every event, down to magnitude $\mathrm{Ml} \approx-1.5$. The cut-off magnitude in the Gutenberg-Richter relationships is $\mathrm{Ml} \approx-0.5$, with a maximal magnitude of 3.2. The inferred properties of all families are gathered in auxiliary materials (Table S1).

\section{Results}

\subsection{Location Geometry}

Between 10 April and 14 June 2014 (days 3 to 68 after the mainshock), 5,947 events, belonging to 31 different families, have been relocated (see Figure 3 and Movie S1). The depth sources lie between -4 and $-10 \mathrm{~km}$. At these depths, all events occurred in the crystalline basement of the Argentera massif, without any seismicity in the sedimentary layers at shallower depths.

The main alignment of seismicity describes a $5 \mathrm{~km}$ long, $4 \mathrm{~km}$ wide plane, striking N160. With event depths lying between 5 and $9.5 \mathrm{~km}$, this plane is dipping $\sim 60 \mathrm{~W}$. This dip is confirmed by the 3-points method applied on all events. This plane orientation is compatible with the $\mathrm{N} 160,55^{\circ} \mathrm{W}$ fault plane inferred from the focal mechanism of the mainshock (Thouvenot et al., 2016), with the mainshock hypocenter located in its deeper part. At first order, the plane on which seismicity aligns (later refereed as main structure) might be the mainshock fault. 
When looking in more details at the seismicity distribution on and around this main plane, the geometry is quite complex (see Figure 3):

- Deep events (7.5-9.5 km): In the lowest part of the main structure, both 3-point or covariance analysis show that families of events align on planes that are striking as the main structure (N160), but dipping either $\sim 70^{\circ} \mathrm{E}$ or $\sim 65^{\circ} \mathrm{W}$ (see Table S1 and Figure S2). The planes dipping west might be either on the main plane or parallel to it, while the ones dipping East might be conjugate structures. For example, the family denoted $\mathrm{Fa}$ on Figure 3 and composed of 1,250 located events aligns on a N160, $60^{\circ} \mathrm{E}$ planar structure which is $2.5 \mathrm{~km}$ long and $\sim 1 \mathrm{~km}$ wide.

- Intermediate depth events $(6.5-8 \mathrm{~km})$ : A smaller density of events characterizes the middle part of the main structure.

- Shallow events (5-6.5 km): In the upper part of the main structure, the seismicity aligns on planes which are striking N20-to- $60^{\circ}$ and dipping $\sim 65^{\circ} \mathrm{E}$ or ${ }^{\circ} \mathrm{W}$ or on elongated structures, oriented normal to the main structure $\left(\mathrm{N} \sim 60^{\circ}, \sim 60^{\circ} \mathrm{E}\right)$. Therefore, the seismicity on those structures do not belong to the main structure either.

Therefore, on average, the seismicity is drawing a broad alignment compatible with the fault plane of the mainshock. In details, the 3-points and the covariance analysis show that most of the seismic sources gather on planes with dip and/or azimuth strongly different from the main structure. Therefore, this shows that a large part of the seismicity did not occur on the main fault plane. Even if the mainshock location was erroneous by more than $1 \mathrm{~km}$ vertically, most of the seismicity would have occurred above the mainshock plane, in the hanging wall. Deep and shallow events are also aligned on planes with very different dips and azimuths. It suggests either that the stress field changes between depths of 9 and $5 \mathrm{~km}$, or that different mechanical processes are at play.

Finally, there are a few clusters of seismic events that do not belong to the main structure (later referred to as outer families). These clusters can be either shallow or deep (from 4 to $10 \mathrm{~km}$ depth), above the main structure or up to $3 \mathrm{~km}$ far away from it. They do not show any consistent strikes and dips, even if some of them are striking N0-to- $50^{\circ}$. These clusters do not seem to have active connection with the main structure, as there are seismic gaps between them and the main structure. For example, the cluster denoted Fs on Figure 3 is

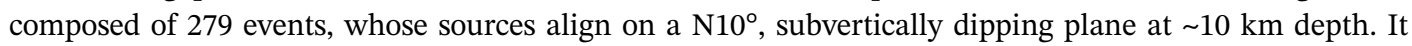
occurred $2 \mathrm{~km}$ away from the main structure $(3.5 \mathrm{~km}$ from the mainshock), without any seismic event located in between.

\subsection{Space, Time, and Magnitude Behavior}

Figure 4 shows the temporal distribution and the spatiotemporal behavior of the seismicity, on average for all events, and for two selected families ( $F a$ and $F$, see Figure 3). When looking at the average behavior of all events together, the number of events decays with time. The same pattern is observed for the deeper families, such as $\mathrm{Fa}$, while family $\mathrm{Fs}$ and the outer families show a swarm-like behavior, with a delayed increase and decrease of seismicity. Most of the shallow families, in the upper part of the main structure, also behave like a swarm. For example, family $F s$ is mainly active from 55 to 65 days after the mainshock, with nearly no event before.

To refine the time distributions, we can fit a modified Omori's law (Utsu, 1961) of the form $N(t)=K /$ $(c+t)^{p}$, where $N$ is the number of events; $t$ is the time; and $K, c$, and $p$ are constants to determine. This fit is performed for the period in which events have been relocated (days 4 to 62, see Figure 5) using a maximum likelihood method (Ogata, 1999). From day 4, the relocated events show a decay with an exponent of $p=0.77$, that is, lower than 1 . We checked that this value does not come from a bias of the catalog, as (1) all detected events, (2) all relocated events, and (3) relocated events with magnitude above the completeness magnitude $(\mathrm{Ml}=-0.5)$ lead to similar values. Note that the detection catalog shows a smaller exponent in the first 4 days, leading to an average $p=0.65$ exponent when looking at all the aftershock period. This change in the decay rate may be due either to a bias in the catalog in the first few days, or to a change in the seismic behavior. The families that behave as aftershocks, such as $\mathrm{Fa}$, strongly differ from the classical Omori's law, as they decay much faster, with a $p=1.41$ exponent. On the other hand, the swarm families decay very slowly, with an exponent $p=0.18$. Therefore, while the overall seismic response is decaying more slowly than what is commonly 
a)

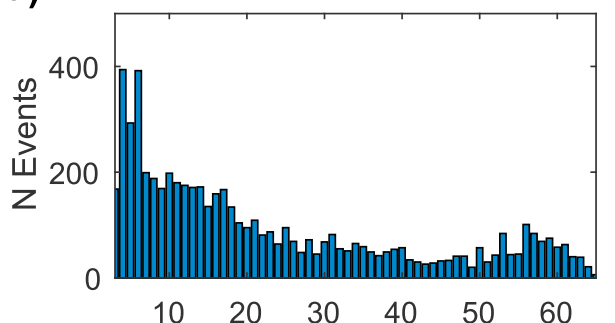

b)
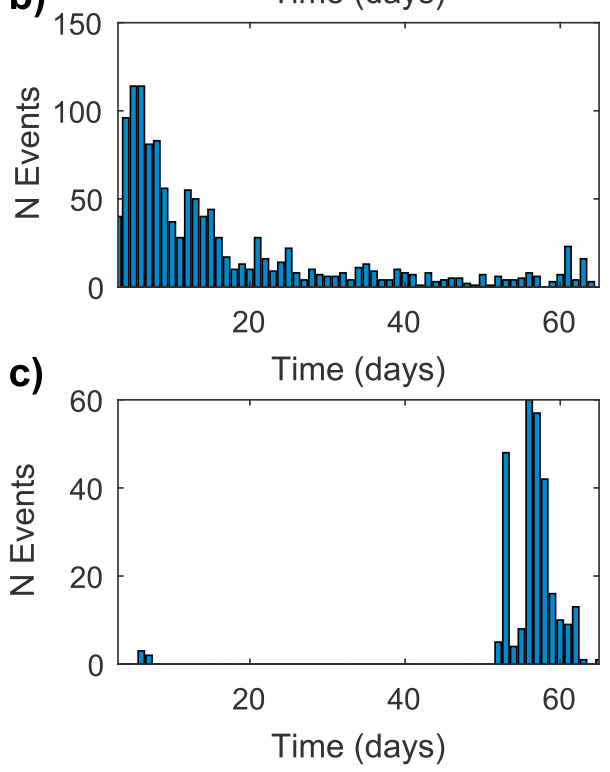

d)

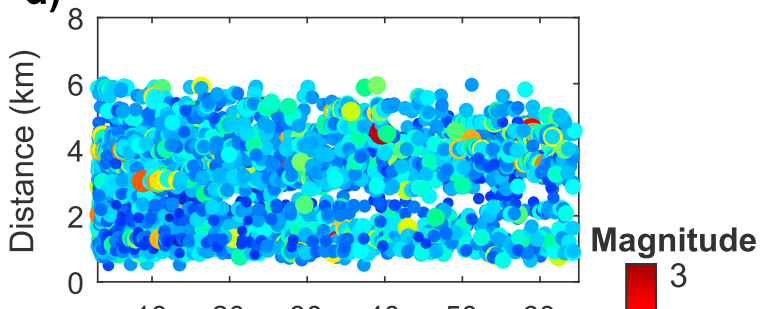

$\begin{array}{llllll}10 & 20 & 30 & 40 & 50 & 60\end{array}$

e)

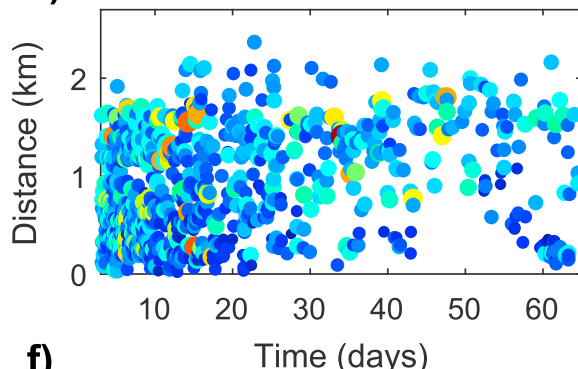

f)

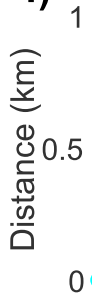

2.5

2

1.5

1

0.5

0

$-0.5$

$-1$

Figure 4. Temporal (left columns) and spatiotemporal (right column) distributions of the seismicity, for (a) and (d) all located events; (b) and (e) the Fs family; and (c) and (f) for the Fa family (see Figure 3). For the spatiotemporal distributions ( $\mathrm{d}-\mathrm{f}$ ), the colors show the magnitude of events. In all panels, time is in days from the mainshock. In (d), distances are computed from the mainshock hypocenter; in (e) and (f), they are computed from the first event in families $\mathrm{Fs}$ and $\mathrm{Fa}$, respectively. In panel (f), the green and red lines are the best fit for a constant velocity migration $(\mathrm{V}=0.1 \mathrm{~km} /$ day $)$ and for a diffusion law fit $\left(\mathrm{D}=0.05 \mathrm{~m}^{2} / \mathrm{s}\right)$, respectively.

observed, the families that compose it show either a faster-than-usual decay after the mainshock perturbation, or a delayed swarm behavior.

There is no overall clear migration of the seismicity after the mainshock. The events occurred at up to $6 \mathrm{~km}$ from the mainshock hypocenter 3 days after it, and this distance did not grow with time (see Figure 4). As already stated by Thouvenot et al. (2016), the mainshock reactivates the entire area quasi-instantaneously. Similar behaviors are observed for families with decaying number of events, for example, $F a$. However, when looking in deeper details inside the swarm families, clear migrations can be observed. Therefore, while no spatiotemporal variations are observed within the deep families of the main structure, most of the clusters that are either outside or shallow show a seismic migration (see Table S1). Assuming a constant migration velocity, the seismic front grows with a speed varying between 6 and $85 \mathrm{~m}$ /day depending on the clusters. Such velocity is too slow to be attributed to slow-slip (Lohman \& McGuire, 2007), but may be related to fluid-pressure diffusion. If the seismicity occurred at the fluid-pressure front, the distance-time (so-called R-t diagram) distribution envelops can be fitted by a diffusion law, such as $R=\sqrt{(} \pi \mathrm{D} t$ ) (Shapiro et al., 1997). The diffusion coefficient $D$ is found to vary between $2 \mathrm{e}-3$ and $6 \mathrm{e}-2 \mathrm{~m} / \mathrm{s}^{2}$, which leads to permeability estimation in the range $1 \mathrm{e}-16$ to $5 \mathrm{e}-14 \mathrm{~m}^{2}$.

The magnitude distribution also differs among families (Figure 6). Fitting a Gutenberg-Richter law (maximum likelihood fit; Ogata \& Katsura, 1993) to the full set of events gives a b-value slightly lower than $1(b=0.95 \pm 0.01)$, where the uncertainty is computed as $b / \sqrt{ } \mathrm{N}$, with $\mathrm{N}$ the number of events (Aki, 1965). 


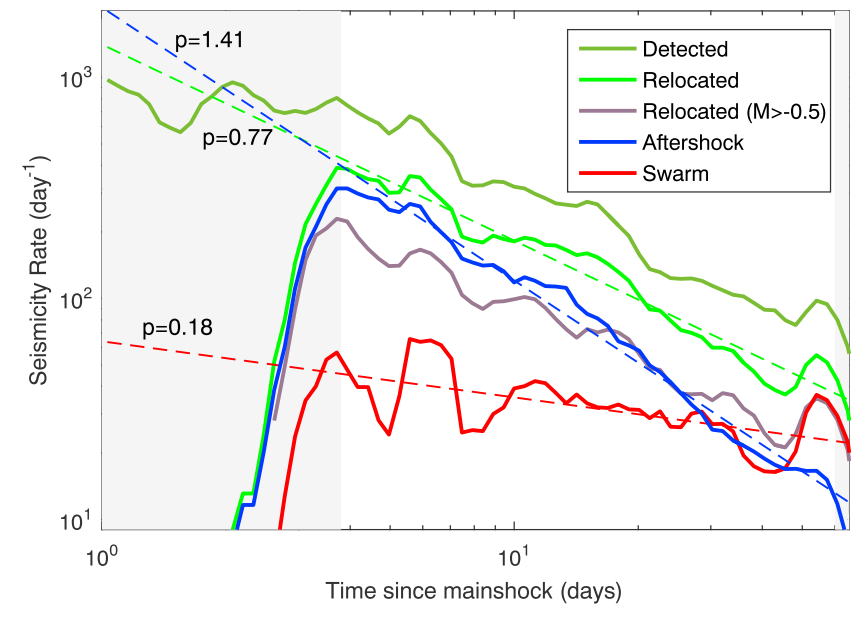

Figure 5. Seismicity rate for all detected events, relocated events, relocated events with magnitude greater than the magnitude of completeness $(\mathrm{M}>-0.5)$, relocated events belonging to aftershock families and relocated events belonging to swarm-like families. The dashed lines indicate the best fit for a modified Omori's law, with a slope of $p=1.41$ (aftershocks), $p=0.77$ (relocated and detected events), and $p=0.18$ (swarms).
The aftershock-like families are characterized by a slightly higher value of $\mathrm{b}=0.99 \pm 0.02$. However, a lower exponent is found for the swarm-like families, with a mean $b$-value of $0.85 \pm 0.02$. The same observations can be made on individual families, despite a variability in the b-values and the magnitude completeness (see Figure 6 and Table S1). For example, the family $F a$, at the bottom of the main structure, has a b-value of $1.01 \pm 0.03$ while the swarm cluster Fs shows $b=0.81 \pm 0.05$.

\section{Discussion}

\subsection{Complex Spatial Distribution of Seismicity}

The aftershocks of the 7 April 2014 Ubaye earthquake mainly align on a large plane, whose dips and azimuths are consistent with the fault plane of the mainshock. This fault plane is shown in Figure 3 as an oversimplified straight line and is more likely to be more complex, with some curvatures. However, improbable changes in dips between subvertical to less than $30^{\circ}$ are required for this structure to pass through the aftershock cluster. Furthermore, most of the family structures show strikes and dips that are not compatible with the main fault plane. Therefore, the seismicity seems to occur on conjugate structures or on subparallel planes, mainly around the deeper and shallower ends of the main fault plane. The crust around the main fault should be highly fractured, inherited from its complex tectonic history. The structures highlighted by the event alignments could also correspond to the fault damaged zone, as a splay network developing at the tips of the main fault (Perrin et al., 2016). The occurrence of aftershocks on different structures than the mainshock one is not exceptional. The aftershock sequence of the 1996 Pyrenees earthquake (Ml 5.2) also distributes on structures with various orientations (Pauchet et al., 1999). The Mogul swarm (Nevada, United States) locations highlighted a main fault and its damaged zone (Ruhl et al., 2016). On the San Jacinto fault, most aftershocks of the Mw 5.2 Borrego Springs earthquake do not occur on the main plane, but on branches orthogonal to it (Ross, Hauksson, et al., 2017). Therefore, the aftershock location highlights the complex interaction between the stress perturbations and the damaged zone of the fault.

Most of the seismicity is not located on the assumed mainshock fault, but above it. The coseismic stress changes might have been negative on the main fault plane and in its footwall, leading to a lack of seismicity in these zones. Alternatively, it could be a consequence of the previous 2012 mainshock, which share similar location and mechanisms with the 2014 one (Thouvenot et al., 2016). It may have discharged the stress on this fault plane, except on its bottom end where the 2014 earthquake occurred. Such an asymmetric distribution was also observed for aftershocks on large faults in California (Zaliapin \& Ben-Zion, 2011) and interpreted as due to the difference in materials properties between both sides of the faults (Rubin \& Ampuero, 2007). The damaged zone might also be strongly asymmetric, due to a preferential rupture directivity. However, even if the 2012 earthquake showed a clear rupture directivity toward the south-east (Courboulex et al., 2013), rupture propagation was not observed directional for the 2014 earthquake. Alternatively, the mainshock slip might have changed the permeability of the fault, leading to new fluid paths and upward migration of the fluids, which then induced the swarm behaviors observed in the upper part of the main structure.

Finally, the structures at depth $(7.5-9.5 \mathrm{~km})$, with a $\sim \mathrm{N} 160^{\circ}$ azimuth, show a very different orientation from the shallower structures $(5-6.5 \mathrm{~km})$, striking N20-to-50 . The seismic clusters outside the main structure occurred on structures with various azimuths. By inverting focal mechanisms for the 2003-2004 crisis (Leclère et al., 2013) and the 2012-2015 crisis (Fojtíková \& Vavryčuk, 2018), the stress field shows a subhorizontal minor component $\sigma 3$ oriented $\sim \mathrm{N} 100^{\circ}$ and a N11 to $29^{\circ} \sigma 1$ component, with a plunge between $12^{\circ}$ and $61^{\circ}$ depending on the authors. Such stress field is compatible with slip on $\mathrm{N} 160^{\circ}$ structures, such as the deep ones. However, shallow structures and outer ones are badly oriented toward the stress state. For example, the Fs structure is subvertically dipping with an $\mathrm{N} 20^{\circ}$ azimuth which is aligned with the major stress component. As shown by Leclère et al. (2013) for the 2004-2005 crisis, such heterogeneous 

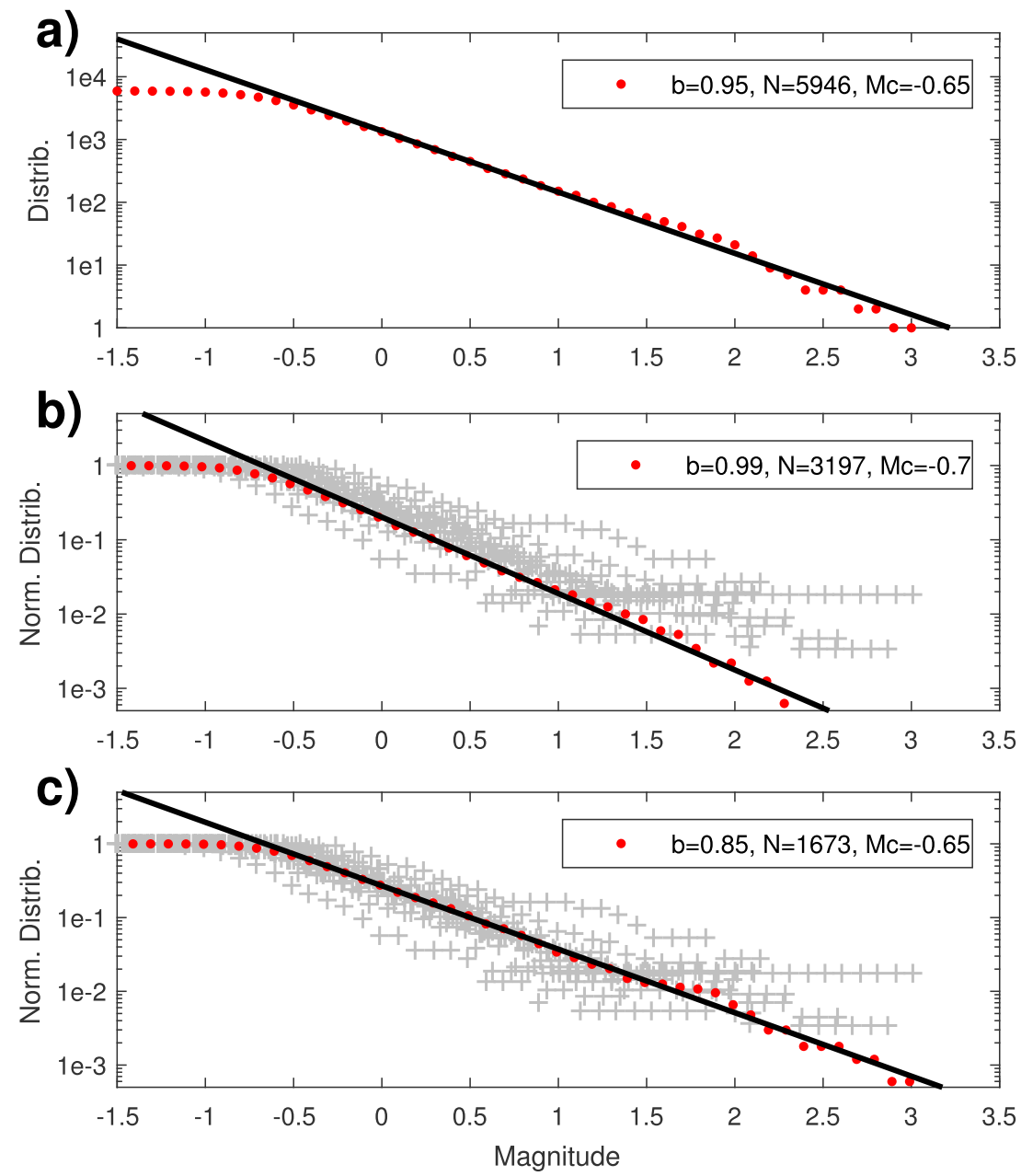

Figure 6. Cumulative magnitude distribution (red dots) for (a) all events, (b) events belonging to aftershock-like families, and (c) events belonging to swarm-behaving families. Black lines are their best fitting trend, with the computed b-value and completeness magnitude in the legend box. In panels (b) and (c), gray crosses show the normalized distributions for every families.

structures, and therefore mechanisms, are not compatible with a unique, static, stress state. Fojtíková and Vavryčuk (2018) also found that a very low friction coefficient of $0.2-0.3$ is required. Therefore, either high fluid-pressure or heterogeneous stress state are required to induce slips on badly oriented structures. A detailed analysis of the mechanisms is however required to study in details the link between the seismicity and the stress state.

\subsection{Two Processes: Fluid-Pressure and Stress Transfer}

Among families, the spatial, temporal, and magnitude distributions reveal two clearly distinct behaviors. On one side, $53.7 \%$ of the located events belong to families that exhibit classical patterns of aftershock sequences: Their rates show a power law decay in the rate of events with time, without any migration patterns, their magnitudes follow a Gutenberg-Richter law with $\mathrm{b} \approx 1$, and they are located close to the mainshock. Such events are mostly located in the surroundings of the deeper part of the main fault. Only one area in the upper part and none of the outside clusters shows such behavior (Figure 7). They are mainly located at less than $3 \mathrm{~km}$ from the mainshock hypocenter, that is, at less than a typical fault length for a magnitude 5 earthquake. This is a classical observation for aftershocks, which are mainly on or around the rupture area, with a fast decay away from it (e.g., Harris, 1998). Therefore, these events are likely to be triggered by the static stress transferred from the mainshock (Stein, 1999), and they participate to rebalance the stress after the earthquake perturbation. 

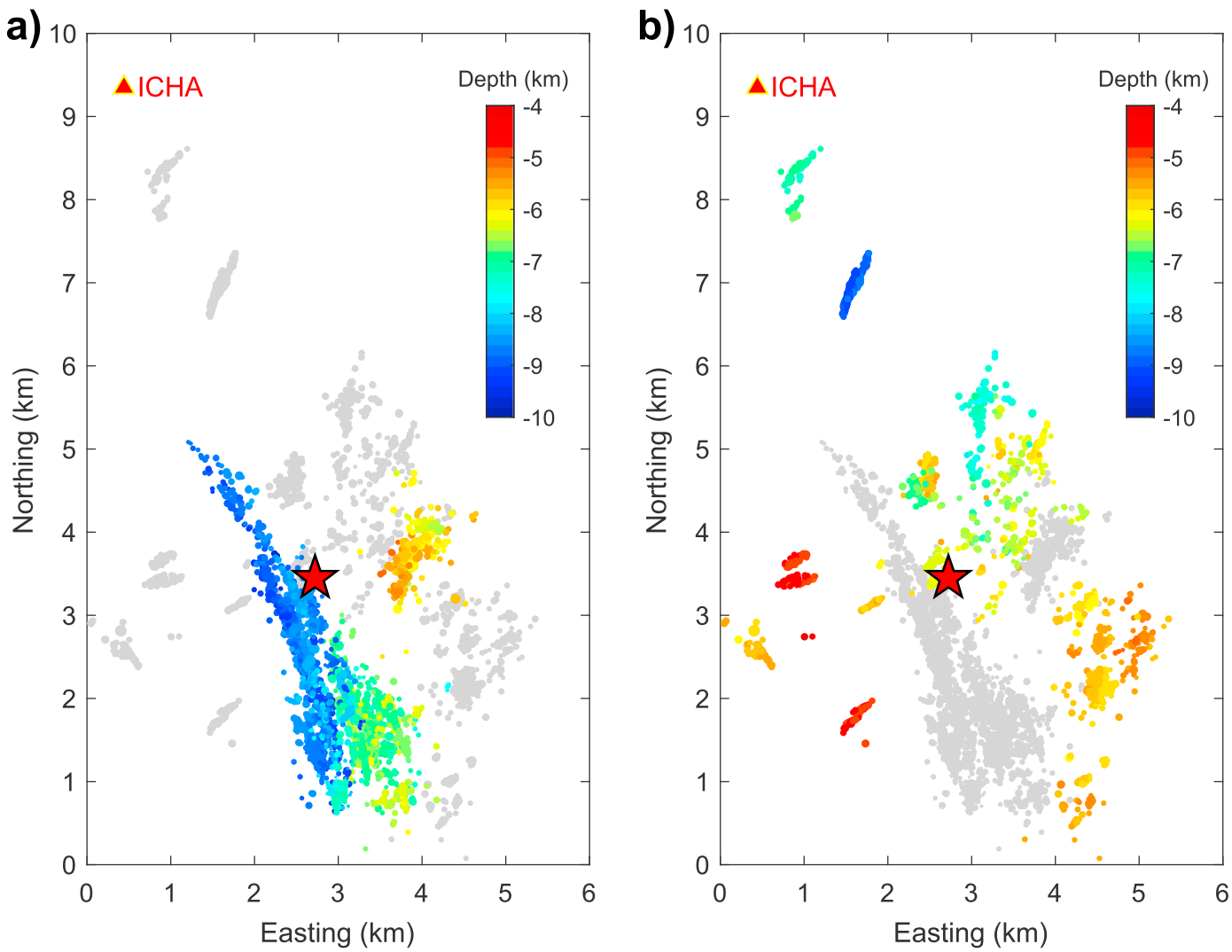

Figure 7. Location map with colorscale indicating the depth for events that belong to (a) aftershock-like families and (b) swarm-like and uncertain families.

On the other side, more than $28 \%$ of the events belongs to families with a swarm-like behavior. (1) Their maximum rate is reached days to months after the mainshock, with the largest event in the middle of the sequence; (2) they occurred at larger distances from the mainshock hypocenter (mainly between 3 and $6 \mathrm{~km}$ ); (3) the rate of events shows an emergent increase and a slow decrease. Most of the outer families and of the shallow ones, but none of the deep ones, share this behavior (Figure 7). Among these families, most of them show a spatiotemporal migration of seismicity. Assuming a constant-rate migration leads to a mean velocity of about $0.1 \mathrm{~km} /$ day. Such slow velocities are not consistent with slow-slip processes, for which observed speeds are about 0.1 to $1.0 \mathrm{~km} / \mathrm{hr}$ (Roland \& McGuire, 2009). With a linear fluid diffusion process (Shapiro et al., 1997), diffusivity ranges from 0.002 to $0.06 \mathrm{~m}^{2} / \mathrm{s}$. Similar values were observed in Southern California (Chen et al., 2012), Corinth Rift (Duverger et al., 2015), or geothermal areas (Shapiro et al., 1997). Therefore, these events are likely induced by fluid-pressure diffusion. These families are also characterized by a low b-values in the magnitude distribution (Gutenberg-Richter law), with b-value ranging between 0.75 and 0.9 . Fluid-induced seismicity usually shows b-values larger than 1 , but also lower than 1 in extensional context such as in this study (Ibs-von Seht et al., 2008). Finally, the remaining 18\% of events belong to families with a mix behavior, that is, with a power law temporal decay at the beginning, and a swarm activity later on. This latter number is quite small, meaning that on nearly $80 \%$ of the structures, the seismicity is controlled by a single process, and not by a mix of processes.

The differences between these two behaviors may also be increased by structural differences. While the aftershock sequences occurred on large (up to $3 \mathrm{~km}$ long) and planar NW-SE structures as evidenced in the geology, the swarm-like clusters describe structures that are smaller than $1 \mathrm{~km}$ long, with various orientation and shapes. Particularly, the seismicity highlights several elongated structures that can be related to the intersection of two faults. Therefore, a lack of large faults in the upper part of the main plane, with a suitable orientation for slip, might explain the swarm-like behaviors. However, this does not explain the slower-than-usual decay of the event rates or the delay in the seismicity onset for the swarmlike clusters. 


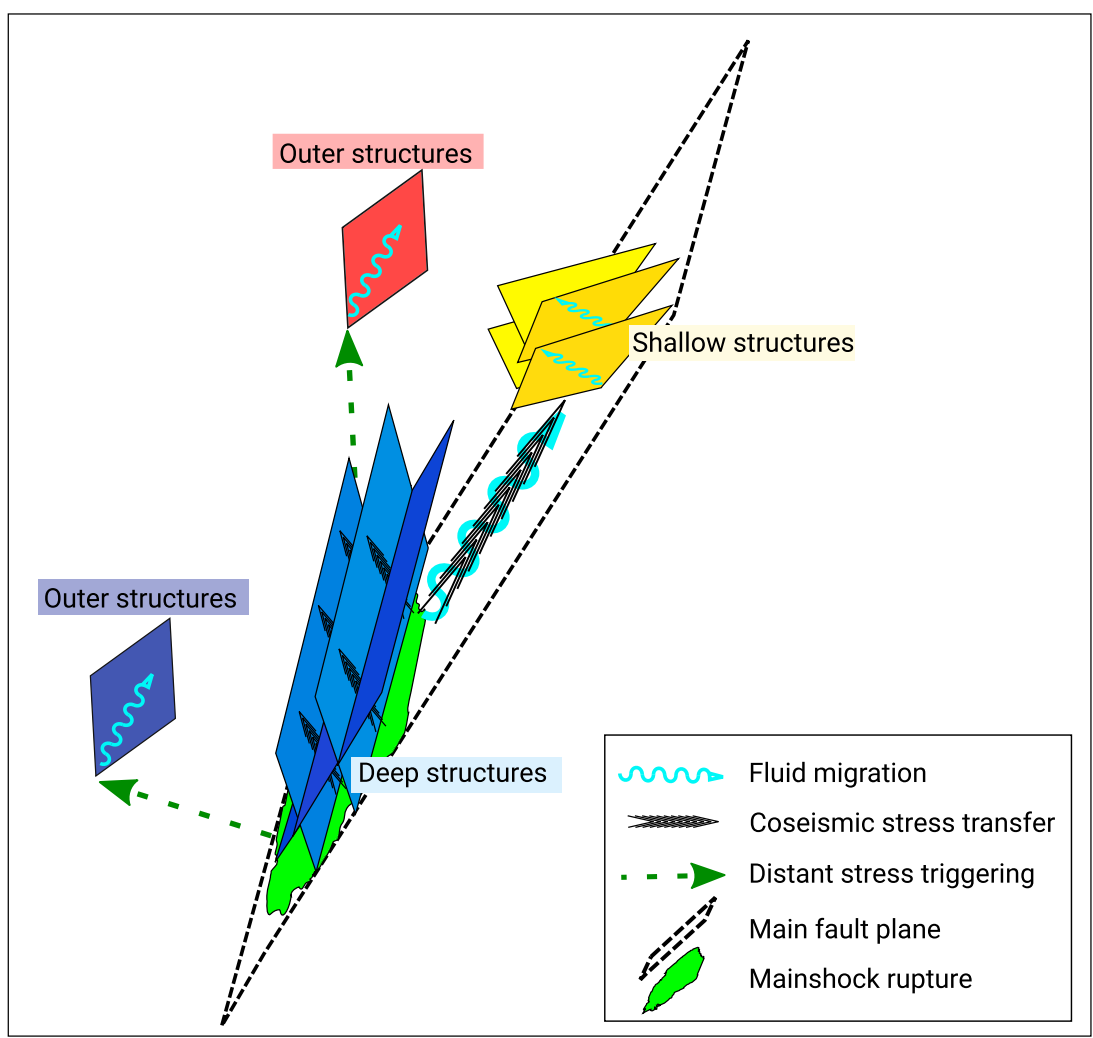

Figure 8. Conceptual model for the processes driving the aftershock sequence.

Therefore, we suggest that two different processes, which are spatially segregated, occurred. Close to the mainshock hypocenter, seismicity follows an aftershock-like behavior, in response to the coseismic Coulomb stress transfer. At larger distances, seismicity is dominated by swarm behaviors, likely induced by fluid-driven processes. On average, the aftershock sequence nearly decays as predicted by an Omori's law (though with a smaller than 1 exponent), and follows a Gutenberg-Richter law with a $b \approx 0.95$ value. However, this classical response masks the sum of two different behaviors: the $1 / \mathrm{t}$ decay originates from the sum of very fast $(\mathrm{p} \approx 1.4$ ) decays and swarm-like distributions. The $\mathrm{b}$-value is an average of $\mathrm{a} b \approx 1$ value for the aftershocks and $\mathrm{a} b \approx 0.85$ for the fluid-induced events. Therefore, it is likely that these two classical laws, commonly observed after mainshocks, originate from the regional average of different processes (Ben-Zion, 2008), that we were here able to separate.

\subsection{Conceptual Model}

Several processes, linked to fluid-pressure and stress transfer, are therefore required to explain the relationships between the mainshock and its aftershock sequence. Ross, Rollins, et al. (2017) reached a similar conclusion, with the observations of fluid-induced and stress-driven aftershocks after the 2010 M7.2 El MayorCucapah earthquake in the Yuha Desert (United States). Miller et al. (2004) also involved $\mathrm{CO}_{2}$ degassing to explain the aftershocks in the 1997 Umbria-Marche sequence (Italy). Interestingly, using a waveform-based classification, we are here able to isolate the processes because of their spatial segregation and to summarize them into a conceptual model (Figure 8).

First, at close distance from the mainshock and large depths, the seismicity is directly triggered by the coseismic stress transfer in the damaged zone of the hanging wall of the fault. Therefore, it highlights the complex interaction between the coseismic stress perturbation and the damaged zone. The shallower activity required fluid, as it is dominated by swarm behavior on structures badly oriented with the stress field. Fluid pressurization may directly originate from the coseismic stress perturbation. As shown by Bosl and Nur (2002) after the Landers earthquake (1992), the region of coseismic positive Coulomb stress correlates 
with areas with pore pressure increased in response to the mainshock perturbation. Alternatively, the mainshock slip, through dilatancy processes, may have open new fluid paths, following the fault-valve behavior of Sibson (1990). Overpressurized fluids then migrated upward, inducing the seismicity of the shallow families.

Finally, some swarms occurred far from the mainshock, with areas devoid of events between them. If a fluid diffusion process started from the mainshock or the aftershock sequence on the main structure, it would be likely that seismic events would highlight the fluid paths. Furthermore, some swarms are at similar depths as the mainshock: A 3-to-6 km purely horizontal fluid migration is not likely. Therefore, a distant triggering is required. It might be due to coseismic or postseismic stress change, or to some dynamic triggering by the seismic waves of the mainshock or large aftershocks. Dynamic triggering has been shown to be efficient in areas with fluids (Brodsky et al., 2003; De Barros et al., 2017; Hill \& Prejean, 2015). These transient perturbations might then open some fluid paths within the outer structures, leading to a fluid-pressure diffusion and inducing seismicity with a spatiotemporal migration.

Such dual behaviors, both in the seismicity and in the processes, are specific to the areas of Barcelonnette. Around this area, and despite similar tectonic context, the inner part of the Alpine chain do not behave like that and shows a more diffuse seismicity. Therefore, such behavior is related to an anomaly, likely related to fluids. Other localized areas, for example, the area of Vallorcine, in the northern part of the French Alps, also show similar anomalies, with alternating mainshocks (such as the 8 September $2005 \mathrm{Ml}$ 4.5; Fréchet et al., 2011) and seismic swarms. These small and localized areas, gather much higher rate of seismicity than the rests of the Alps, and should have therefore a specific response in terms of earthquake hazard mitigation.

Acknowledgments

We thank SISMOB, the French seismic mobile pool and Géoazur for providing us with the seismological instrumentation for the temporary deployment, David Ambrois, Jerôme Chèze, and Xavier Martin from Géoazur and Cécile Cornou and Christophe Voisin from Isterre for the deployment itself. Continuous seismic data are available online through the RESIF portal (http://seismology.resif. $\mathrm{fr} /$ ). RESIF is a national Research Infrastructure, recognized as such by the French Ministry of Higher Education and Research. It is managed by the RESIF Consortium, composed of 18 Research Institutions and Universities in France and it is additionally supported by a public grant overseen by the French National Research Agency (ANR) as part of the "Investissements d'Avenir" program (reference: ANR-11-EQPX-0040) and the French Ministry of Ecology, Sustainable Development and Energy. SURF data are from the permanent French Network FR (https://doi.org/ 10.15778/RESIF.FR), the other data are distributed as XG_2014 temporary network (https://doi.org/10.15778/RESIF. XG2014). Deployment and processing has been supported by Interreg-Alcotra France-Italy projects CASSAT $\left(\mathrm{N}^{\circ} 181\right.$, 2007-2013) and RISVAL ( $\mathrm{N}^{\circ} 1510$, 2014-2020) funded on European Regional Development Fund (ERDF). The catalog of relocated events is available upon request at L. De Barros (debarros@geoazur.unice.fr).We thank the associate editor (Y. Ben Zion), G. De Landro, and an anonymous reviewer for their useful comments.

\section{Conclusion}

Since 2012, earthquakes have struck the Ubaye valley continuously, making this area the most active one in the French Alps. In 2014, a Ml 4.8 earthquake was a source of concern for the population. The aftershock sequence broadly aligns on a large plane, consistent with the mainshock fault. However, families individually align on distinct planes. Therefore, a majority of the seismic sources do not occur on the main fault plane, but on conjugate structures belonging or damage zone of the main fault. About $50 \%$ of the seismic events originate from coseismic stress transfer, at short distance from the mainshock. The remaining seismicity is further away, and requires fluid-pressure diffusion and distant, maybe dynamic, triggering. Such different processes required a highly fractured medium with pervasive fluids at depths. This area is therefore peculiar as deep fluid processes in addition to stress perturbations control the alternating swarms and mainshock/aftershock sequences. Such an aftershock sequence has therefore an intermediate behavior between the two end-members that are the fluid-induced seismicity and the tectonic-driven earthquakes. On average, the seismicity rate decay is slower than expected by an Omori's law, and the GutenbergRicher b-value is close to 1 . This average behavior is however resulting from two strongly different patterns and processes. Therefore, it is likely that such dual behaviors are more common than expected, and hidden behind classical responses.

\section{References}

Aki, K. (1965). Maximum likelihood estimate of $\mathrm{b}$ in the formula $\log \mathrm{N}=\mathrm{a}-\mathrm{bM}$ and its confidence limits. Bulletin of the Earthquake Research Institute, University of Tokyo, 43, 237-239.

Ben-Zion, Y. (2008). Collective behavior of earthquakes and faults: Continuum-discrete transitions, progressive evolutionary changes, and different dynamic regimes. Reviews of Geophysics, 46, RG4006. https://doi.org/10.1029/2008RG000260

Bernard, P., Briole, P., Meyer, B., Lyon-Caen, H., Gomez, J. M., Tiberi, C., et al. (1997). The M s = 6.2, June 15, 1995 Aigion earthquake (Greece): Evidence for low angle normal faulting in the Corinth rift. Journal of Seismology, 1(2), 131-150. https://doi.org/10.1023/ A:1009795618839

Bigot-Cormier, F., Poupeau, G., \& Sosson, M. (2000). Differential denudations of the Argentera Alpine external crystalline massif (SE France) revealed by fission track thermochronology (zircons, apatites). Comptes Rendus de l'Académie des Sciences. Série II, Sciences de la Terre et des Planètes, 330, 363-370.

Bogdanoff, S., Michard, A., Mansour, M., \& Poupeau, G. (2000). Apatite fission track analysis in the Argentera massif: Evidence of contrasting denudation rates in the external crystalline massifs of the Western Alps. TerraNova, 12(3), 117-125. https://doi.org/10.1046/ j.1365-3121.2000.123281.x

Borghi, A., Aoudia, A., Javed, F., \& Barzaghi, R. (2016). Precursory slow-slip loaded the 2009 L'Aquila earthquake sequence. Geophysical Journal International, 205(2), 776-784.

Bosl, W. J., \& Nur, A. (2002). Aftershocks and pore fluid diffusion following the 1992 Landers earthquake. Journal of Geophysical Research, 107(B12), 2366. https://doi.org/10.1029/2001JB000155 
Brodsky, E. E., Roeloffs, E., Woodcock, D., Gall, I., \& Manga, M. (2003). A mechanism for sustained groundwater pressure changes induced by distant earthquakes. Journal of Geophysical Research, 108(5), 2390. https://doi.org/10.1029/2002JB002321

Chen, X., Shearer, P. M., \& Abercrombie, R. E. (2012). Spatial migration of earthquakes within seismic clusters in Southern California: Evidence for fluid diffusion. Journal of Geophysical Research, 117, B04301. https://doi.org/10.1029/2011JB008973

Collettini, C., \& Barchi, M. R. (2002). A low-angle normal fault in the Umbria region (Central Italy): A mechanical model for the related microseismicity. Tectonophysics, 359(1-2), 97-115. https://doi.org/10.1016/S0040-1951(02)00441-9

Corsini, M., Ruffet, G., \& Caby, R. (2004). Alpine and late-Hercynian geochronological constraints in the Argentera massif (Western Alps). Eclogae Geologicae Helvetiae, 97, 3-15. https://doi.org/10.1007/s00015-004-1107-8

Courboulex, F., Dujardin, A., Vallée, M., Delouis, B., Sira, C., Deschamps, A., et al. (2013). High-frequency directivity effect for an Mw 4.1 earthquake, widely felt by the population in southeastern France. Bulletin of the Seismological Society of America, 103(6), $3347-3353$. https://doi.org/10.1785/0120130073

Daniel, G., Prono, E., Renard, F., Thouvenot, F., Hainzl, S., Marsan, D., et al. (2011). Changes in effective stress during the 2003-2004 Ubaye seismic swarm, France. Journal of Geophysical Research, 116, B01309. https://doi.org/10.1029/2010JB007551

De Barros, L., Deschamps, A., Sladen, A., Lyon-Caen, H., \& Voulgaris, N. (2017). Investigating dynamic triggering of seismicity by regional earthquakes: The case of the Corinth Rift (Greece). Geophysical Research Letters, 44, 10,921-10,929. https://doi.org/10.1002/ 2017GL075460

De Barros, L., Guglielmi, Y., Rivet, D., Cappa, F., \& Duboeuf, L. (2018). Seismicity and fault aseismic deformation caused by fluid injection in decametric in-situ experiments. Comptes Rendus Geoscience, 350, 464-475. https://doi.org/10.1016/j.crte.2018.08.002

Delacou, B., Sue, C., Champagnac, J.-D., \& Burkhard, M. (2004). Present-day geodynamics in the bend of the western and central Alps as constrained by earthquake analysis. Geophysical Journal International, 158(2), 753-774. https://doi.org/10.1111/j.1365246X.2004.02320.x

Dewey, J., Helman, M., Turco, E., Hutton, D., \& Knott, S. (1989). Kinematics of the western Mediterranean. In: Alpine tectonics, M. Coward, D. Dietrich and G.G. Parks. Geological Society of London, Special Publication, 45, 265-283. https://doi.org/10.1144/GSL. SP.1989.045.01.15

Duverger, C., Godano, M., Bernard, P., Lyon-Caen, H., \& Lambotte, S. (2015). The 2003-2004 seismic swarm in the western Corinth rift: Evidence for a multiscale pore pressure diffusion process along a permeable fault system. Geophysical Research Letters, 42, 7374-7382 https://doi.org/10.1002/2015GL065298

Fehler, M., House, L., \& Kaieda, H. (1987). Determining planes along which earthquakes occur: Method and application to earthquakes accompanying hydraulic fracturing. Journal of Geophysical Research, 92(B9), 9407-9414. https://doi.org/10.1029/ JB092iB09p09407

Felzer, K. R., \& Brodsky, E. E. (2006). Decay of aftershock density with distance indicates triggering by dynamic stress. Nature, 441(7094), 735-738. https://doi.org/10.1038/nature04799

Fojtíková, L., \& Vavryčuk, V. (2018). Tectonic stress regime in the 2003-2004 and 2012-2015 earthquake swarms in the Ubaye Valley, French Alps. Pure and Applied Geophysics, 175(6), 1997-2008. https://doi.org/10.1007/s00024-018-1792-2

Fréchet, J., \& Pavoni, N. (1979). Etude de la sismicité de la zone briançonnaise entre Pelvoux et Argentera (Alpes Orientales) à l'aide d'un réseau de stations portables. Eclogae Geologicae Helvetiae, 118(8), 4461-4476. https://doi.org/10.1002/jgrb.50297

Fréchet, J., Thouvenot, F., Frogneux, M., Deichmann, N., \& Cara, M. (2011). The M w 4.5 Vallorcine (French Alps) earthquake of 8 September 2005 and its complex aftershock sequence. Journal of Seismology, 15(1), 43-58. https://doi.org/10.1007/s10950-010-9205-8

Fry, N. (1989). Southwestward thrusting and tectonics of the Western Alps. Geological Society of London, Special Publication, 45(1), 83-109. https://doi.org/10.1144/GSL.SP.1989.045.01.05

Gibbons, S. J., \& Ringdal, F. (2006). The detection of low magnitude seismic events using array-based waveform correlation. Geophysical Journal International, 165(1), 149-166. https://doi.org/10.1111/j.1365-246X.2006.02865.X

Guglielmi, Y., Cappa, F., Avouac, J. P., Henry, P., \& Elsworth, D. (2015). Seismicity triggered by fluid injection-induced aseismic slip. Science, 348(6240), 1224-1226. https://doi.org/10.1126/science.aab0476

Hainzl, S., Fischer, T., \& Dahm, T. (2012). Seismicity-based estimation of the driving fluid pressure in the case of swarm activity in Western Bohemia. Geophysical Journal International, 191(1), 271-281. https://doi.org/10.1111/j.1365-246X.2012.05610.x

Harris, R. A. (1998). Introduction to special section: Stress triggers, stress shadows, and implications for seismic hazard. Journal of Geophysical Research, 103(B10), 24,347-24,358. https://doi.org/10.1029/98JB01576

Hill, D. P., \& Prejean, S. (2015). Dynamic triggering. In G. Schubert (Ed.), Earthquake seismology, treatise on geophysics (2nd ed., Vol. 4, pp. 273-304). Oxford: Elsevier. https://doi.org/10.1016/B978-0-444-53802-4.00078-6

Ibs-von Seht, M., Plenefisch, T., \& Klinge, K. (2008). Earthquake swarms in continental rifts-A comparison of selected cases in America, Africa and Europe. Tectonophysics, 452(1-4), 66-77. https://doi.org/10.1016/j.tecto.2008.02.008

Jenatton, L., Guiguet, R., Thouvenot, F., \& Daix, N. (2007). The 16,000-event 2003-2004 earthquake swarm in Ubaye (French Alps). Journal of Geophysical Research, 112(B11). https://doi.org/10.1029/2006JB004878

Keranen, K. M., Weingarten, M., Abers, G. A., Bekins, B. A., \& Ge, S. (2014). Sharp increase in central Oklahoma seismicity since 2008 induced by massive wastewater injection. Science, 345(6195), 448-451. https://doi.org/10.1126/science.1255802

Larroque, C., Béthoux, N., Calais, E., Courboulex, F., Deschamps, A., Déverchère, J., et al. (2001). Active and recent deformation at the Southern Alps-Ligurian basin junction. Geologie en Mijnbouw, 80(3/4), 255-272.

Larroque, C., Delouis, B., Godel, B., \& Nocquet, J. M. (2009). Active deformation at the southwestern Alps-Ligurian basin junction (FranceItaly boundary): Evidence for recent change from compression to extension in the Argentera massif. Tectonophysics, 467(1-4), 22-34. https://doi.org/10.1016/j.tecto.2008.12.013

Leclère, H., Fabbri, O., Daniel, G., \& Cappa, F. (2012). Reactivation of a strike-slip fault by fluid overpressuring in the southwestern FrenchItalian Alps. Geophysical Journal International, 189(1), 29-37.

Leclère, H., Daniel, G., Fabbri, O., Cappa, F., \& Thouvenot, F. (2013). Tracking fluid pressure buildup from focal mechanisms during the 2003-2004 Ubaye seismic swarm, France. Journal of Geophysical Research: Solid Earth, 118, 4461-4476. https://doi.org/10.1002/ jgrb. 50297

Lohman, R. B., \& McGuire, J. J. (2007). Earthquake swarms driven by aseismic creep in the Salton Trough, California. Journal of Geophysical Research, 112, B04405. https://doi.org/10.1029/2006JB004596

Michelini, A., \& Bolt, B. A. (1986). Application of the principal parameters method to the 1983 Coalinga, California, aftershock sequence. Bulletin of the Seismological Society of America, 76(2), 409-420.

Miller, S. A., Collettini, C., Chiaraluce, L., Cocco, M., Barchi, M., \& Kaus, B. J. (2004). Aftershocks driven by a high-pressure $\mathrm{CO}_{2}$ source at depth. Nature, 427(6976), 724-727. https://doi.org/10.1038/nature02251 
Nicolas, M., Santoire, J.-P., \& Delpech, P.-Y. (1990). Intraplate seismicity: New seismotectonic data in Western Europe. Tectonophysics, 179, 27-53. https://doi.org/10.1016/0040-1951(90)90354-B

Nocquet, J. M., Sue, C., Walpersdorf, A., Tran, T., Lenôtre, N., Vernant, P., et al. (2016). Present-day uplift of the western Alps. Scientific Reports, 6, 28404. https://doi.org/10.1038/srep28404

Ogata, Y. (1999). Seismicity analysis through point-process modeling: A review. In M. Wyss, K. Shimazaki, \& A. Ito (Eds.), Seismicity patterns, their statistical significance and physical meaning (Vol 155, pp. 471-507). Basel: Pageoph Topical Volumes. Birkhäuser. https:// doi.org/10.1007/978-3-0348-8677-2_14

Ogata, Y., \& Katsura, K. (1993). Analysis of temporal and spatial heterogeneity of magnitude frequency distribution inferred from earthquake catalogues. Geophysical Journal International, 113(3), 727-738. https://doi.org/10.1111/j.1365-246X.1993.tb04663.x

Pauchet, H., Rigo, A., Rivera, L., \& Souriau, A. (1999). A detailed analysis of the February 1996 aftershock sequence in the eastern Pyrenees, France. Geophysical Journal International, 137(1), 107-127. https://doi.org/10.1046/j.1365-246x.1999.00776.x

Perfettini, H., \& Avouac, J. P. (2004). Postseismic relaxation driven by brittle creep: A possible mechanism to reconcile geodetic measurements and the decay rate of aftershocks, application to the Chi-Chi earthquake, Taiwan. Journal of Geophysical Research, 109, B02304. https://doi.org/10.1029/2003JB002488

Perrin, C., Manighetti, I., \& Gaudemer, Y. (2016). Off-fault tip splay networks: A genetic and generic property of faults indicative of their long-term propagation. Comptes Rendus Geoscience, 348(1), 52-60. https://doi.org/10.1016/j.crte.2015.05.002

RESIF (1995). RESIF-RLBP French Broad-band network, RESIF-RAP strong motion network and other seismic stations in metropolitan France. RESIF - Réseau Sismologique et géodésique Français. Seismic Network. doi:10.15778/RESIF.FR

Roland, E., \& McGuire, J. J. (2009). Earthquake swarms on transform faults. Geophysical Journal International, 178(3), 1677-1690. https:// doi.org/10.1111/j.1365-246X.2009.04214.X

Ross, Z. E., Hauksson, E., \& Ben-Zion, Y. (2017). Abundant off-fault seismicity and orthogonal structures in the San Jacinto fault zone. Science Advances, 3(3), e1601946. https://doi.org/10.1126/sciadv.1601946

Ross, Z. E., Rollins, C., Cochran, E. S., Hauksson, E., Avouac, J. P., \& Ben-Zion, Y. (2017). Aftershocks driven by afterslip and fluid pressure sweeping through a fault-fracture mesh. Geophysical Research Letters, 44, 8260-8267. https://doi.org/10.1002/2017GL074634

Rubin, A. M., \& Ampuero, J. P. (2007). Aftershock asymmetry on a bimaterial interface. Journal of Geophysical Research, 112 , B05307. https://doi.org/10.1029/2006JB004337

Ruhl, C. J., Abercrombie, R. E., Smith, K. D., \& Zaliapin, I. (2016). Complex spatiotemporal evolution of the 2008 Mw 4.9 Mogul earthquake swarm (Reno, Nevada): Interplay of fluid and faulting. Journal of Geophysical Research: Solid Earth, 121, 8196-8216. https://doi.org/ 10.1002/2016JB013399

Sanchez, G., Rolland, Y., Corsini, M., Braucher, R., Bourlès, D., Arnold, M., \& Aumaître, G. (2010). Relationships between tectonics, slope instability and climate change: Cosmic ray exposure dating of active faults, landslides and glacial surfaces in the SW Alps. Geomorphology, 117, 1-13. https://doi.org/10.1016/j.geomorph.2009.10.019

Sellami, S., Kissling, E., Thouvenot, F., \& Fréchet, J. (1995). Initial reference velocity model for seismic tomography in the western Alps, 20th Gen. Ass. Europ. Geophys. Soc., Hamburg.

Shapiro, S. A., Huenges, E., \& Borm, G. (1997). Estimating the crust permeability from fluid-injection-induced seismic emission at the KTB site. Geophysical Journal International, 131(2), F15-F18. https://doi.org/10.1111/j.1365-246X.1997.tb01215.x

Sibson, R. H. (1990). Conditions for fault-valve behaviour. Geological Society, London, Special Publications, 54(1), 15-28.

Sira, C., Schlupp, A., Schaming, M., Chesnais, C., Cornou, C., Dechamp, A., et al. (2014). Séisme de Barcelonnette du 7 avril 2014 , Rapport du BCSF, BCSF2014-R1, 76p.

Stein, R. S. (1999). The role of stress transfer in earthquake occurrence. Nature, 402(6762), 605-609. https://doi.org/10.1038/45144

Sue, C., \& Tricart, P. (2003). Neogene to ongoing normal faulting in the inner Western Alps: A major evolution of the late alpine tectonics. Tectonics, 22(5), 1050. https://doi.org/10.1029/2002TC001426

Thouvenot, F., Jenatton, L., Scafidi, D., Turino, C., Potin, B., \& Ferretti, G. (2016). Encore Ubaye: Earthquake swarms, foreshocks, and aftershocks in the southern French Alps. Bulletin of the Seismological Society of America, 106(5), 2244-2257. https://doi.org/10.1785/ 0120150249

Utsu, T. (1961). A statistical study on the occurrence of aftershocks. Geophysical Magazine, 30, 521-605.

Vallée, M., Nocquet, J. M., Battaglia, J., Font, Y., Segovia, M., Regnier, M., et al. (2013). Intense interface seismicity triggered by a shallow slow slip event in the Central Ecuador subduction zone. Journal of Geophysical Research: Solid Earth, 118, 2965-2981. https://doi.org/ 10.1002/jgrb.50216

Vernant, P., Hivert, F., Chery, J., Steer, P., Cattin, R., \& Rigo, A. (2013). Erosion-induced isostatic rebound triggers extension in low convergent mountain ranges. Geology, 41(4), 467-470. https://doi.org/10.1130/G33942.1

Vidale, J. E., \& Shearer, P. M. (2006). A survey of 71 earthquake bursts across southern California: Exploring the role of pore fluid pressure fluctuations and aseismic slip as drivers. Journal of Geophysical Research, 111, B05312. https://doi.org/10.1029/2005JB004034

Waldhauser, F., \& Ellsworth, W. L. (2000). A double-difference earthquake location algorithm: Method and application to the northern Hayward fault, California. Bulletin of the Seismological Society of America, 90(6), 1353-1368. https://doi.org/10.1785/0120000006

Waldhauser, F., Ellsworth, W. L., Schaff, D. P., \& Cole, A. (2004). Streaks, multiplets, and holes: High-resolution spatio-temporal behavior of Parkfield seismicity. Geophysical Research Letters, 31, L18608. https://doi.org/10.1029/2004GL020649

Walpersdorf, A., Pinget, L., Vernant, P., Sue, C., Deprez, A., \& RENAG team (2018). Does long-term GPS in the Western Alps finally confirm earthquake mechanisms? Tectonics, 37(10), 3721-3737. https://doi.org/10.1029/2018TC005054

Zaliapin, I., \& Ben-Zion, Y. (2011). Asymmetric distribution of aftershocks on large faults in California. Geophysical Journal International, 185(3), 1288-1304. https://doi.org/10.1111/j.1365-246X.2011.04995.x

Zhao, L., Paul, A., Guillot, S., Solarino, S., Malusà, M. G., \& Zheng, T. (2015). First seismic evidence for continental subduction beneath the western Alps. Geology, 43(9), 815-818. https://doi.org/10.1130/G36833.1 